\title{
Shocks in Macroeconomic variables and Stock Market Stability: Case Study of KSE-100 Index
}

\author{
Asmat Ullah ${ }^{1}$, Dr. Syed Waqar Hussain², Zahoor Khan ${ }^{3}$, \\ Dr. Muhammad Rafiq ${ }^{4}$
}

\begin{abstract}
This study was conducted to quantify the stability impacts of shocks in leading macroeconomic variables on Karachi Stock Exchange (KSE)-100 index using annual data from 2000-2010. Four macroeconomic variables, Average annual exchange rate (EXR), inflation rate CPI based (INFR), real GDP growth rate (RGDP) and unemployment rate (UEMR), have been used. Dynamic Distributed lag (DDL) model was selected after experimenting on different forms and specifications. Selections were based on recent advance measure of co-integration i.e. "Bonds Testing" proposed by (Pesaran, Shin, EF Smith, 2001) which can be applied even on small number of observations. Based on empirical analysis, inflation rate (CPI based) and unemployment rate (UMER) were dropped due to its insignificance in the present context. Major findings of this study includes that shocks in current index of Karachi stock exchange are due to, other factors constant, one period lag shocks in its own index, real GDP and average annual exchange rate. Whereas current GDP growth has strong significant impact compared to one period lag GDP. So our main conclusion is that, shocks in KSE-index to some extent can be controlled by stabilizing main macroeconomic variables such as Real growth rate of GDP, exchange rate even its own stability (i.e. stability of KSE-100 index) have also significant lesson for its future stability.
\end{abstract}

Keywords: Stock Exchange, KSE-100, Unemployment, Inflation rate, real GDP.

\section{Introduction}

The growing importance of stock market, around the world, has accelerated investigations on identifying it's the role in economic growth and development of the country (Nishat \& Shaheen, 2004-05). Since stock market, in any country, channelizes savings and accelerates the activation of investment

1 Lecturer in Economics, Institute of Management Sciences, Hayatabad, Peshawar and M.Phil Student, Preston University Islamabad.

2 Assistant Professor, Institute of Management Sciences, Hayatabad, Peshawar

3 Lecturer in Economics, Department of Economics, University of Peshawar

4 Assistant Professor, Institute of Management Sciences, Hayatabad, Peshawar - Pakistan 
projects which in turn leads to economic prosperity and development. The primary function of the stock market is to act as mediator between savers and investor and harmonize their preferences through its operation. Other functions of stock market include re-allocation of resources among various corporations and sectors and provide liquidity for domestic credit growth and expansion. The Pakistan stock market has been highly volatile over many years, for instance, its recent history of operation as may be assessed from the crashes in March 2005, second quarter of 2006 and most recent crash includes May 2008 to January 2009. The first two of the crashes in the stock market was accumulated effect of speculations and bad governance. The recent most collapse of 2008 and 2009 was mostly due to qualitative factors like judiciary crises, terrorists attacks and assassination of Benazir Bhutto, Chairperson of Pakistan People Party. (Sohail \& Hussain, 2009).

Karachi Stock Exchange (KSE) is the largest and most dynamic stock exchange of the Pakistan. Being the best performing stock exchange for the year 2000 , it total share was $70 \%$ of the total stock transitions. The integration of International stock markets due to globalization, has serious implications for under-developed country like Pakistan particularly its stock markets. High degree of financial integration links stock market's performance with the economic growth of the country and then with macroeconomic variables which in turns affect stock markets functions (Mohammad, Hussain, Jalil, \& Ali, 2009). So the link between leading macroeconomic variables and stock market performance is worth investigation for effective policy formatiom. Though Many studies have been conducted across the world using different sets of variables with different sets of statistical tools for analysis, the present study investigates the stability impact of leading macroeconomic variables on KSE-100 index. Specifically this study is different from previous studies mainly on the grounds: i) it uses major indicators, namely exchange rate, inflation rate, real GDP growth rate and unemployment rate. Ii) the properties of time series are properly analyzed using Augmented-Dukey fuller test and optimal lag structure is achieved using Akiak Information Criterion (AIC), iii) it tests the impacts of shocks in these variables on KSE-100 index with different specifications of the Autoregressive Distributed Lag (ARDL) Models using "Bounds Testing” approaches developed by by (Pesaran, Shin, \& Smith, 2001) and best parsimonous model is selected.

\section{Literature Review}

(Sadeghi, 1992) provided proof on the relationship between unexpected change in the macroeconomic variables and Australian stock market (ASM) 
for the period 1980 to 1991 . The results suggested that that stock return are positively correlated with unexpected change in growth rate of real GDP, exchange rate and unemployment rate while it is negatively co-related with inflation rate and interest rate.

(Ray \& Vina,2004) investigated the connection between macroeconomic variables and Bombay Stock Exchange (BSE) Sensitive Index using data for the year 1994 to 2003. The variables that they have chosen were fiscal deficit, inflation rate, money supply, exchange rate, foreign direct investment, national output, interest rate in the Indian markets. VAR and Artificial Neural Network techniques were used for the results. Their result show that the variables such as interest rate, National output, money supply inflation and exchange rate has significant impact in the stock market while the remaining variables affect stock exchange only marginally.

(Adam \& Tweneboach, 2008) studied the effect of macroeconomic variables on the changing in the stock prices in Ghana for the period 1991 to 2006. They examine both the short-run and long-run relationship between macroeconomic variables and stock market index. The variables were foreign direct investment (FDI), Treasury bill rate (TBR), consumer price index (CPI), and exchange rate (EX). They use Johansen's multivariate co integration test and innovating accounting techniques. The result which they derived was that there is co-integration between the macroeconomic variables and stock prices in Ghana. In the short run inflation and exchange rate influence change in share prices while in the long run it is interest rate that matters

(Rasiah, 2010) investigated short and long-run relationship between various macroeconomic variables and stock market in Malaysia during 1980 to 2006. He used multivariate co integration methodology in order to find out possible relationship between the two variables. The result that he derived from his study was that according to the co integration test and the vector error correction there is a positive long run relation between real stock returns and the macroeconomic variables which are industrial production, consumer price index, money supply and real exchange rate.

(Sariannidis, Giannarakis, Litinas, \& Konteos, 2010)studied the impact of change in returns in the crude oil prices and change in returns in 10 years bond value (as a measure of change in interest rate) on DOW Jones WILSHIRE 5000 (US) indexes. A monthly data from January 2000 to January 2008 analyzed with the GARCH Model was estimated. The result shows that change in the crude oil price affect the stock market while change in the returns of 10 years bond value positively affect US stock market or in the other we can say that interest rate positively affect; US stock market. 
(Monirimanesh \& Fazizadesh, 2010) studied the relationship between macroeconomic variables and stock market in Iran using time series data from 1984 to 2008. The variables were near money, long term deposit investment and consumer price index. For result they use ARDL method. Results show that there exists a positive relation between stock returns and consumer price index.

(Sohail \& Hussain, 2009) studied the long and short-run relations between Lahore Stock Exchange (LSE) and macroeconomic variables in Pakistan using monthly data from December 2002 to May 2008. The variables were consumer price index (CPI), industrial production index (IPI), real effective exchange rate and money supply. The results show that consumer price index has negative impact on stock returns while money supply, real effective exchange rate and industrial production industrial have positive effect on stock returns in the long run.

(Mohammad, Hussain, Jalil, \& Ali, 2009) explored the correlation between macroeconomic variables and stock price of KSE. Variables that were considered for this study were foreign exchange reserves, foreign exchange rate, industrial production index (IPI), whole sale price index (GFCF) and broad money M2. Quarterly data from 1986 to 2008 analyzed which showed that GFCF and IPI has insignificant effect on the stock prices.

(Patelis, 1997) studied the long-run relationship between the macroeconomic variables including consumer price Index (CPI), Short term interest rate (SI), Earnings, term spread and stock prices in US. The sample was that of S \& P 500 stocks for the time period of 1997 to 2006. Variance decomposition and Johansen's co-integration test was used for estimation. The Results suggested that there is a long-run relationship between stock prices and interest rate.

(Gay, 2008) tried to investigate the time-series relationship between macroeconomic variables and stock market index prices of four emerging economies viz; Brazil, Russia, India and China (BRIC) using monthly data from 1999 to 2006. The variables were exchange rate (EX) and oil prices. He used the Box- Jenkins ARIMA model to investigate the relationship. However, there was no significant relationship found between the respective oil prices and exchange rate on the stock market prices of any of the BRIC countries.

(Pilinkus, 2009)studied the short-run relationship between various macroeconomic variables and stock market prices in Lithuania using monthly data From January 2000 to June 2009. The six macroeconomic variables selected 
for the study were Gross Domestic Product (GDP), Consumer Price Index (CPI), Money Supply, short-term interest rate (SIR), Unemployment rate, Exchange Rate (EX), and the OMX Vilinus Index, which is the main Lithuanian Stock Market Index. The results clearly showed that macroeconomic variables are the determinants of stock market prices in Lithuania. GDP and money supply had positive impact while exchange rate, short term interest rate and unemployment rate had negative impact on stock market prices.

(Menike, 2006) investigated the relations between macroeconomic variables and stock prices of Colombo Stock Exchange (CSE) in Sri Lanka, using monthly data from September 1991 to December 2002. The independent variables were exchange rate (EX), Money Supply, Inflation Rate and interest rate while the dependent variable was the stock prices of Colombo Stock exchange (CSE). Multivariate Regression was run for the estimation. The result suggested that inflation rates $\&$ exchange rate had a negative impact on the stock prices in Colombo Stock Exchange.

(Naka, Mukherjee, \& Tufte, 2010) analyzed the stock market of India and macroeconomic variables in India for the period 1960-1995. The variables were Inflation, Domestic Output, and Interest rate, Industrial production index (IPI) and consumer price index (CPI). The model that they used was vector error correction model. Results suggested that inflation is the most significant determinant of Indian stock market and so is the domestic output.

(Adrangi, Chatrath, \& Sanvicente, 2000) studied the impact of macroeconomic variables on stock returns in Brazil, using data from 1986 to July 1997. The variables were Industrial Production Index, which was used as a proxy for real economic activity and inflation. The Johansen and Juselius cointegration test was used for the results. The tests confirmed the long-run equilibrium between general price level, real economic activity and stock prices.

(Gan, Lee, Yong, \& Zhang, 2006) studied the relationship between seven macroeconomic variables and New Zealand stock index (NZSI) using data for the time period January 1999 to January 2003. The variables were inflation rate, Exchange rate (EX), GDP, money Supply (M1), long tern interest rate (LR), short term interest rate (ST) and Domestic Real Oil Price (ROIL). These were the independent variables. The dependent variable was share price index (NZSE40). The study employed Johansen multi-variant co integration test and Granger causality test to determine whether the above variables were co integrated. The Johansen co integration test proved that there was a long run relationship between NZSE40 and the tested macro economic variables tested. 
(Ali, Rehman ur, Yilmaz, Khan, \& Afzal, 2010) examined the relationship between macroeconomic variables and stock market prices in Pakistan using data from June 1999 to December 2008. Macroeconomic variables were inflation, Balances of trade, Exchange rate (EX) and industrial production index (IPI). The statistical tools which they used were unit root Augmented Dickey fuller test, Granger's causality test and Johansen's co-integration test. The results showed that there was a co-integration between industrial production index (IPI) and stock exchange prices.

\section{Research Methodology:}

In order to assess the effect of annual average exchange rate of Pakistani Rupee against U.S dollar (EXR), annual average consumer price index (inflation rate) denoted by INFR, growth in real GDP (RGDP) and annual unemployment rate (UEMR) on the Karachi Stock Index-100 (KSE) measured by annual average of KSE-100. We have used "Bounds Testing" approach developed by by (Pesaran, Shin, \& Smith, 2001) and Wald test for choosing best fit is selected, which is given as:

$\operatorname{LnKSE}=\beta_{0}+\beta_{1} \operatorname{RGDP}+\beta_{2} \mathrm{KSE}_{\mathrm{t}-1}+\beta_{3} \operatorname{LnEXR}_{\mathrm{t}-1}+\beta_{4} \mathrm{RGDP}_{\mathrm{t}-1}+\mathrm{U}_{\mathrm{i}}$

LnKSE \& $\mathrm{KSE}_{\mathrm{t}-1}$ is the natural $\log \&$ first lag value of KSE respectively, $\operatorname{LnEXR}_{\mathrm{t}-1} \& \mathrm{RGDP}_{\mathrm{t}-1}$ is the first lag of log of Annual Average of Exchange Rate and growth of real GDP respectively. Ui is the error term. Model (1) is the special type of Distributed Lag (DDL) Model. The use of the above variables are due to the their vital importance in the present context as shown by (Ali, Rehman ur, Yilmaz, Khan, \& Afzal, 2010) and (Gan, Lee, Yong, \& Zhang, 2006). The stability of all these variables are, theoritically, stabalizing the performance of the stock exchange. The selection of ARDL type modeling is due to availability of less annual data of KSE-1 00 index in particlur. The application of "Bounds Testing" approaches to model(1) does well even in case of small samples (Pesaran, Shin, \& Smith, 2001).

Data range is from 2000-2010, and was taken from various issues of Economic Survey of Pakistan and SBP Annual Reports.

\section{Results and Discussions:}

The resuts of Table No-1(See Appendix) report the Wald test for testing joint significance of the variables. The probability of F-test and Chi-Square represent that the effects of these variables are simultaneously significant. The Table No-2 (See Appendix) shows (Pesaran and Shin 1997) ARDL type 
cointgeration test results which confirms that variables are co-integrated i.e. having long run relationships. So the results of ARDL model (1) are not spurious. Table No-3(See Appendix) reports the results of ARDL model (1), all the coefficients are significant and the value of the R-square is close to $98 \%$ which shows goodness of fit. The fitted values (Predicted values from ARDL model (1) is plotted against the true values which is given in appendix (Figure-1). These fitted values along with true values are close enough which reveals the goodness of fit. The results of the ARDL Model (1) shown in table No-3(See Appedix) shows that KSE-Index is affected by its own lag value positively, and coefficient is significant at $5 \%$ level but with the smaller magnitude. This means that a positive shock last year, produce positive result in the current year and vice versa but the smaller magnitude of the lag KSEindex's coefficient suggests that shocks die soon or KSE-index time series have smaller memory or recall shocks for one lag time period with low magnitude.

\section{Conclusions and Recommendations:}

This paper focused on assessing impact of leading macroeconomic variables on the stock exchange stability (KSE-100). First, we test stationary condition of each variable applying Bond-Test. Secondly, we experiment various functional forms and empirical evidence revealed that the including inflation rate (CPI based) \& UNEMR were not significant, so it were excluded from analysis. Our major findings includes that shocks in current index of Karachi stock exchange are due to, other factors constant, one period lag shocks in its own index, real GDP and average annual exchange rate. Whereas current GDP growth has strong significant impact compared to one period lag GDP. So our main conclusion is that, shocks in KSE-index can be control to some extent by stabilizing main macroeconomic variables such as Real growth rate of GDP, exchange rate even its own stability also have significant lesson for its future stability. It is recommended, in light of the study, that stakeholders should formulate such policy framework through which these leading macroeconomic variables, mentioned above, can be smoothly stabilized.

\section{Appendix:}

Table No-1: Wald Test for Joint Restriction

\begin{tabular}{|l|c|c|}
\hline Test Statistics & Value & Probability \\
\hline F test & 55.33 & 0.041 \\
\hline Chi-square test & 165.96 & 0.001 \\
\hline
\end{tabular}


Table No-2: ARDL Cointegration

\begin{tabular}{|l|c|c|c|c|}
\hline Variables & Co-efficient & Standard Error & T-Ratios & Probability \\
\hline Constant & 1.86 & 0.44 & 4.17 & 0.05 \\
\hline DlnKSE $_{\mathrm{t}-1}$ & -0.23 & 0.06 & -3.68 & 0.06 \\
\hline DRGDP $_{\mathrm{t}-1}$ & 0.04 & 0.006 & 7.41 & 0.01 \\
\hline DLnEXR $_{\mathrm{t}-1}$ & 0.37 & 0.312 & 1.17 & 0.35 \\
\hline LnKSE $_{\mathrm{t}-1}$ & 0.21 & 0.028 & 7.58 & 0.016 \\
\hline RGDP $_{\mathrm{t}-1}$ & -0.05 & 0.011 & -5.35 & 0.03 \\
\hline LnEXR $_{\mathrm{t}-1}$ & -0.80 & 0.15 & 5.36 & 0.032 \\
\hline $\mathrm{F}$ test & 820962 & & & 0.00023 \\
\hline $\mathrm{R}^{2}$ & 0.99 & & & \\
\hline Adjusted R & 0.96 & & & \\
\hline Durbin-Watson d & 3.21 & & & \\
\hline
\end{tabular}

Table N0-3: Estimation of The model (1)

\begin{tabular}{|l|c|c|c|c|}
\hline Variable & Co-effienct & Standard Error & T-Ratios & Probability \\
\hline Constant & -5.998 & 2.68 & -2.25 & 0.501 \\
\hline RGDP & 0.172 & 0.031 & 5.68 & 0.0023 \\
\hline KSE $_{\mathrm{t}-1}$ & 0.000067 & 0.000023 & 2.86 & 0.0353 \\
\hline RGDP $_{\mathrm{t}-1}$ & 0.103 & 0.052 & 2.01 & 0.1010 \\
\hline LnEXR $_{\mathrm{t}-1}$ & 3.12 & 0.6358 & 4.90 & 0.0045 \\
\hline F test & 63.41 & & & 0.000 \\
\hline $\mathrm{R}^{2}$ & 0.98 & & & \\
\hline Log-Likelihood & 8.68 & & & 0.66 \\
\hline ARCH(1,1), F(1,3) & 1.168 & & & 0.92 \\
\hline Normality test, $\chi^{2}$ & 0.16 & & & 0.4234 \\
\hline RESET Test & 0.79 & & & \\
\hline DW Test & 2.65 & & & \\
\hline
\end{tabular}



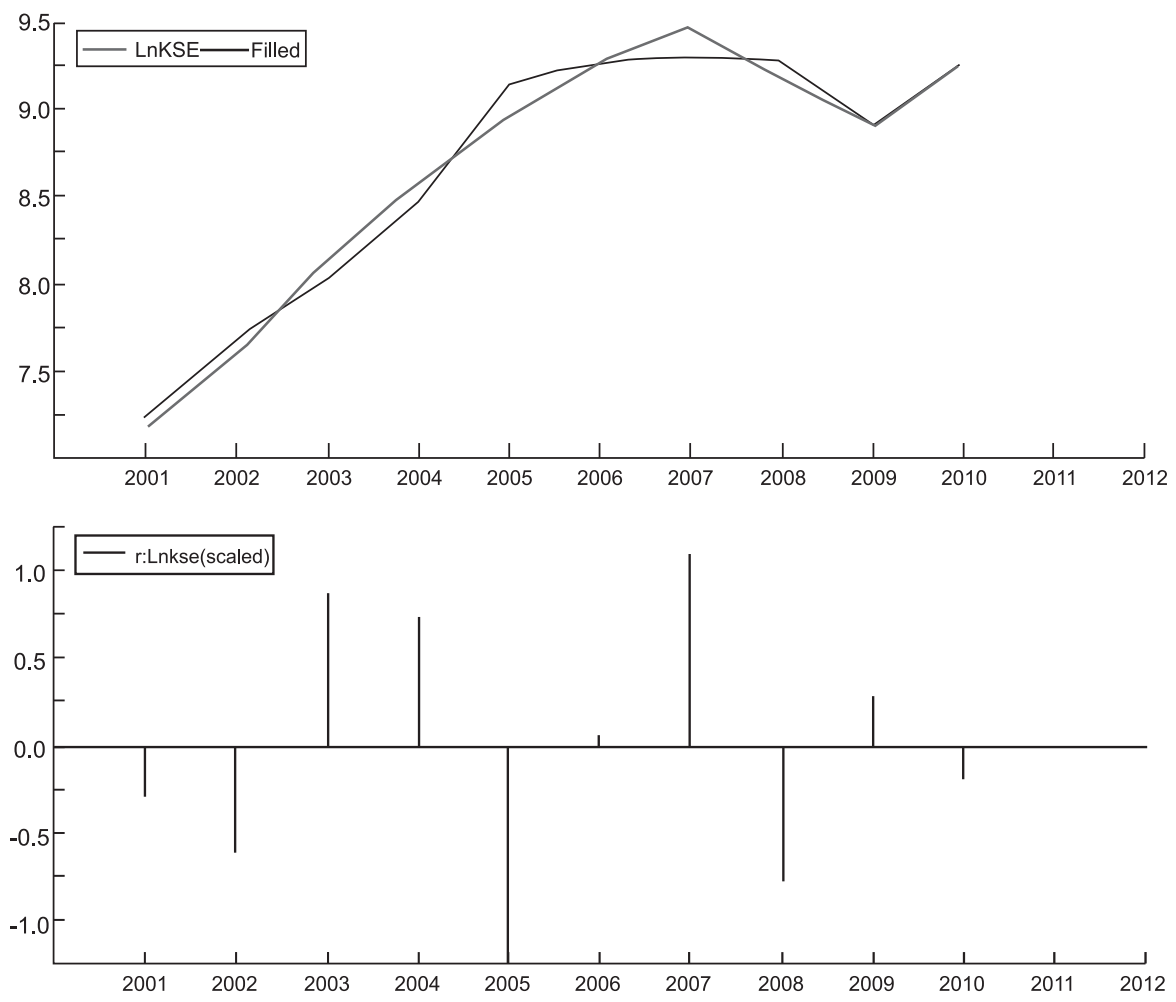

Fig 1: Plot of Fitted Values Versus Actual Values

\section{References}

Adam, M. A., \& Tweneboach, G. (2008). Macroeconomic factors and Stock Market Movement: Evidence from Ghana.

Adrangi, B., Chatrath, A., \& Sanvicente, Z. (2000). Inflation, Output, And Stock Prices: Evidence From Brazil. The Journal of Applied Business Research , 18 (1), 61-77.

Ali, I., Rehman ur, K., Yilmaz, K. A., Khan, A. M., \& Afzal, H. (2010). Cuasal Relationship between Macro-economic Indicators and Stock Exchange Prices in Pakistan. African Journal of Business Management, 4 (3), 312-319.

Gan, C., Lee, M., Yong, A. H., \& Zhang, J. (2006). Macroeconomic Variables and Stock Market Interactions: New Zealand Evidence. Investment Management and Financial Invovations, 3 (4), 89-101.

Gay, D. R. (2008). Effects of Macroeconomic Variables on the Stock Market Retruns for Four Emerging Economies: Brazil, Russia, India, and China. International Business and Economics Research Journal, 7 (3). 
Menike, S. (2006). The Effects of Macroeconomic Variables on Stock Prices in Emerging Sri Lankan Stock Market. Sabaragamuwa University Journal , 6 (1), 50-67.

Mohammad, D. S., Hussain, A., Jalil, A., \& Ali, A. (2009). Impact of macroeconomic variables on the stock Prices: Empirical Evidence in case of KSE (Karachi Stock Exchange). European Journal of Scientific Research , 96-103.

Monirimanesh, N., \& Fazizadesh, A. (2010). The Effects of Monetary variables on the stock Transaction Value in Iran in the period 1984-2008.

Naka, A., Mukherjee, T., \& Tufte, D. (2010). Macroeconomic Variables and the performance of Indian Stock Market.

Nishat, M., \& Shaheen, R. (2004-05). Macroeconomic Factors and Pakistani Equity Market. 20th Annual General Meeting, PIDE. Karachi: Pakistan Institue of Development Economics .

Pesaran, M. H., Shin, Y., \& Smith, R. J. (2001). Bounds Testing Approaches to The Analysis of Level Relationship. Journal of Applied Econometrics , 16 (3), 289-326.

Patelis, A. D. (1997). Stock Return Predictability and the Role of Monetary Policy. Journal of Finance, 52 (2).

Pilinkus, D. (2009). Stock Market and Macroeconomic Variables: Evidences from Lithuania. Economics and Management, 884-891.

Rasiah, V. R. (2010). Macroeconomic Activity and the Malaysain Stock Market: Empirical Evidence of Dynamic Relations. The international Journal of Business and Finance Research, 4 (2).

Ray, P., \& Vani, V. (n.d.). What Moves Indian Stock Market: A Study on Linkage With Real Economy in Post Reform Era.

Ray, P., \& Vina, V. (2004). What Moves indian Stock Market: A Study on Linkage with Real Economy in the Post-Reform Era.

Sadeghi, M. (1992). Stock Market Response to Unexpected Macroeconomic News: The Australian Evidence. IMF Working Paper. IMF.

Sariannidis, N., Giannarakis, G., Litinas, N., \& Konteos, G. (2010). A GARCH Examination of Macroeconomic Effects on U.S Stock Market: A distinguish between the total market index and the sustainbility index. European Research Studies Journal, 8.

Sohail, N., \& Hussain, Z. (2009). Long Run and Short Run Relationships Between Macroeconomic Variables and the stock Prices in Pakistan: The case of Lahor stock exchange. Pakistan Economic and Social Review , 47 (2), 183-189. 